\section{A Cursing Brain? The Histories of Tourette Syndrome}

Howard I Kushner. Harvard University Press. 1999. 303 páginas. ISBN 0-674-18022-4

Recomendo o livro de Kushner, "A Cursing Brain" ou "O Cérebro Blasfemo", para todos aqueles que não se contentam com interpretações ingênuas da história da medicina.

Howard Kushner não é médico, foi psicanalista e atualmente é professor de História da Medicina. Por não se contentar com as teorias do inconsciente para a explicação dos diversos transtornos mentais, dirigiu seu olhar para a pesquisa biológica, e não apenas na área psiquiátrica, como nos mostra seu mais recente interesse, a doença de Kawasaki.

Privilegiado por um espírito crítico, tornou-se um excelente historiador da síndrome de Tourette. A obra há pouco lançada destina-se a ser um clássico, um livro de referência para os estudiosos da síndrome, da história da medicina e da psiquiatria.

Ao longo dos 12 capítulos do livro, Kushner nos conta o nascimento, o desenvolvimento, o apogeu e a queda da síndrome e do seu estudo, como se fosse a história de um império que hoje, ressurgido, reina sob a égide da Tourette Syndrome Association (TSA).

Ele destrincha os diversos ângulos pelos quais o problema foi encarado ao longo do tempo. Derruba mitos, como quando nos conta que nem Charcot, nem o próprio Gilles de La Tourette examinaram diretamente a Marquesa de Dampierre, o caso número um visto e descrito por Itard em 1825 e que inicia a maioria dos artigos dos pesquisadores que se põem a escrever sobre o tema.

Causa perplexidade quando aponta que, teorias supostamente novas, como a de que infecções das vias aéreas superiores pudessem causar tiques - o que vem sendo estudado pelo grupo de Susan Swedo no Instituto Nacional de Saúde Mental Americano (NIMH) - já eram aventadas desde o início do século XIX. Ou quando se sabe que a relação entre a febre reumática e os tiques já era pressuposta no mesmo século.

Mais estupefaciente é o fenômeno que ele denomina "amnésia histórica", referindo-se ao fato de que quando Taranta e Stollerman demonstraram, em 1956, a relação entre a Coréia de Sydenham e uma infecção estreptocócica prévia, desconheciam que em 1890 já se faziam afirmações semelhantes.
O autor analisa, também, os motivos que levaram o primeiro artigo americano, que defendia explicitamente a origem biológica dos tiques, a ser rejeitado em todos os periódicos científicos dos Estados Unidos. Em meados desse século, as concepções psicanalíticas predominavam nas explicações etiológicas dos tiques, e qualquer artigo publicado que se referisse a fatores orgânicos deveria incluir uma análise dos fatores psicodinâmicos envolvidos, ainda que de forma claramente conciliatória. Assim, o casal Shapiro, que se chocou frontalmente com as concepções vigentes ao demonstrar a eficácia dos neurolépticos no tratamento dos tiques, teve de publicar seu artigo no europeu British Journal of Psychiatry em 1968.

Howard Kushner também exerce sua veia crítica quando desnuda o império da TSA, uma entidade formada na década de 70 que congrega pacientes com a síndrome de Tourette e seus familiares, financia pesquisas, promove congressos e reúne os maiores pesquisadores mundiais da área. Além disso, mobiliza milhões de dólares por ano, fazendo a propaganda da síndrome por meio de artistas renomados, pacientes famosos, e tornando os "tiqueurs" personagens de filmes de cinema, como em "The Tic Code", recém-lançado nos EUA que deverá, creio, chegar ao Brasil.

Enfim, trata-se de uma obra completa, que descreve o quadro clínico, as teorias etiopatogênicas, os tratamentos disponíveis no passado, alguns da atualidade, e, "de quebra", as fofocas dos bastidores de um transtorno intrigante. Uma síndrome que vem sendo cada vez mais compreendida, mas que não tem cura, para desespero de muitos pacientes graves e dos profissionais que em alguns momentos não conseguem ajudá-los.

E tudo isso em uma linguagem acessível, dirigida a leigos, com muitas referências e notas explicativas, o que a torna irresistível para quem quer que se interesse pelo tema.

Ana Gabriela Hounie Aluna do doutorado do Departamento de Psiquiatria da Faculdade de Medicina da Universidade de São Paulo 